\title{
Pedological aspects in the functioning of spring niches as transition zones between underground and superficial parts of the water cycle in a river basin
}

\author{
Jerzy Jonczak \\ Department of Geomorphology and Quaternary Geology, \\ Pomeranian University in Słupsk, Partyzantów 27, 76-200 Słupsk \\ e:mail: jonczak@apsl.edu.pl
}

\begin{abstract}
The aim of the study was to characterize the soils of spring niches in the valley of the Jarosławianka River in the context of its functioning in the transition zone between underground and superficial parts of the water cycle in the river basin. Five spring niches, representing different soil types (proper gley soils, peat-like soils, peat-mud soils) were studied. Small-scale relief in nearby water seepages is an important factor, which determined the direction of pedogenesis in spring niches. The relief can enhance or hinder accumulation of organic matter. Specific characteristics of soil-forming environment of spring niches (water surplus and its permanent flow through the soil) are reflected in some chemical properties of the soils (low concentration of active and plant-available forms of N, P and K) and properties of soil organic matter (a low rate of the humification process). Soil organic matter strongly affects the sorption and buffer properties of the soils. Ionic composition of the soil sorption complex is determined by the chemistry of feeding waters. More than $99.3 \%$ of total cations are bases, especially calcium.
\end{abstract}

Key words: hydrogenic soils, water cycling, soil properties, soil organic matter.

\section{Introduction}

Spring niches are transition zones between underground and superficial parts of water cycle in river basin (Jekatierynczuk-Rudczyk 2005; Mazurek 2006). Water plays important role in functioning of spring niches. Quantity and quality of supplying water effects plant communities (Osadowski 2006; Wołejko 1996) and the direction of pedogenesis. The surplus of water makes conditions for development of hydrogenic soils. Properties of the soils reference to the character of past and present plant communities, as well as chemistry of supplying waters. Soil, as basic structural and functional component of the ecosystems of spring niches, influenced on the properties of lotic water. Transformation of the chemistry of water can be deep even in small spring niches (Jekatierynczuk-Rudczyk 2005, 2006, 2007). The complex of physical and chemi- cal properties of the soils, as well as the intensity of biochemical processes (connected with functioning of plant communities and soil microflora and fauna), determined direction and range of the transformation. Soil physical, chemical, sorption and buffer properties, which are determined by the amount and quality of soil organic matter play an important role.

The aim of the study was to characterize physical, chemical, sorption and buffer properties as well as some properties of organic matter of the soils of spring niches in the valley of the Jarosławianka River in the context of its functioning in the transition zone between underground and superficial parts of the water cycle in the river basin. 


\section{Materials and methods}

Jarosławianka is a small river located in the area of a lateglacial depression of the Sławieńska Plain. The river basin has a character of a spring basin, $5.74 \mathrm{~km}^{2}$ in area. Superficial deposits are very acid and low permeable hollow clays and silts or kame deposits, flat-dipping on very compact, calcareous glacial tills. Between hollow or kame deposits and glacial tills, sandy interbeddings occur, which are water-bearing layers. The lower part of the Jarosławianka River is incised in superficial deposits more than $10 \mathrm{~m}$. The incision, which is the effct of rapid water runoff from a postglacial lake, exposed the water-bearing layer. Recently, numerous water seepages are active along the slopes of the river valley. In the vicinity of some water seepage areas, the ground becomes boggy and spring niches develop.

The studies were conducted in five spring niches in the lower part of the Jarosławianka River. One soil profile was made in the central part of each spring niche. The soils were described according to the Taxonomy of Polish Soils (1989). Two volume samples using $100 \mathrm{~cm}^{3}$ rings and one sample as a monolith were taken from each soil horizon. The following parameters were analyzed in the samples:

- bulk density using $100 \mathrm{~cm}^{3}$ steel rings;

- specific density by the burette method;

- total porosity -calculated on the basis of bulk density and specific density;

- specific surface area by the method of adsorption of glycerin vapors;

- grain size distribution by the mixed pipette and sieve method;

- soil organic matter (SOM) content as a weight loss on ignition in $550^{\circ} \mathrm{C}$;

- reaction in $\mathrm{H}_{2} \mathrm{O}$ and $1 \mathrm{~mol} \cdot \mathrm{dm}^{-3}$ solution of $\mathrm{KCl}$;

- the content of total organic carbon (TOC) by Alten's method;

- the content of total organic nitrogen (TON) by Kjeldahl's method;

- the content of easily hydrolyzing nitrogen $\left(\mathrm{N}_{\mathrm{h}}\right)$ in solution of $0.25 \mathrm{M} \mathrm{H}_{2} \mathrm{SO}_{4}$;

- the content of water-extractable (active) forms of nitrogen, phosphorus and potassium after shaking the soil and water in the weight proportion of $1: 10$ for 1 hour. The following was analyzed in the solution: the total amount of dissolved organic nitrogen and ammonium nitrogen (DON) by Kjeldahl's method, nitrate nitrogen $\left(\mathrm{N}-\mathrm{NO}_{3}\right)$ with sodium salicylate, phosphate $\left(\mathrm{P}_{\mathrm{a}}\right)$ by the molybdenum blue method, potassium $\left(\mathrm{K}_{\mathrm{a}}\right)$ by flame emission spectrometry;

- the content of total phosphorus $\left(\mathrm{P}_{t}\right)$ and potassium $\left(\mathrm{K}_{t}\right)$ in the solution after digestion in a mixture of $40 \% \mathrm{HF}$ and $60 \% \mathrm{HClO}_{4}$ in the volumetric proportion of $3: 1$.
The concentration of elements was determined by the aforementioned methods;

- the content of plant-available forms of phosphorus $\left(\mathrm{P}_{\mathrm{pa}}\right)$ and potassium $\left(\mathrm{K}_{\mathrm{pa}}\right)$ by Egner-Riehm method;

- the content of exchangeable bases $\left[\mathrm{Ca}^{2+}, \mathrm{Mg}^{2+}, \mathrm{K}^{+}, \mathrm{Na}^{+}\right]$ in $1 \mathrm{~mol} \cdot \mathrm{dm}^{-3}$ and $\mathrm{pH}=7.0$ solution of $\mathrm{CH}_{3} \mathrm{COONH}_{4}$. Concentration of $\mathrm{Ca}, \mathrm{K}$ and $\mathrm{Na}$ was analyzed by flame emission spectrometry, $\mathrm{Mg}$ by the versenate method;

- exchangeable acidity $\left[\mathrm{H}_{\mathrm{w}}\right.$ and $\left.\mathrm{Al}_{\mathrm{w}}\right]$ by Sokolov's method;

- buffer properties by Arrhenius' method;

- fractional composition of humus by the method of Kononova and Belčikova (Dziadowiec \& Gonet 1999). The following parameters were determined in the humus: the content of carbon in easily soluble organic components (fraction $\mathrm{C} 3$ ), humic acids (CKH1, $\mathrm{CKH} 2$ ), fulvic acids (CKF1), residue after extraction (CPP). The humification rate was calculated as: $((\mathrm{CKH} 1+\mathrm{CKF} 1) * 100) / \mathrm{TOC}$;

- absorbance values of $0.01 \%$ alkaline solutions of humic acids at a wavelength of 465 and $665 \mathrm{~nm} . \mathrm{E}_{4 / 6}$ ratio was calculated as absorbance $465 \mathrm{~nm} /$ absorbance $665 \mathrm{~nm}$.

\section{Results and discussion}

Proper gley soils, peat-like soils and peat-mud soils are typical for spring niches in the valley of the Jarosławianka River. A different direction of the soil development in such spring niches was determined by different locations of water seepages on the valley slopes and small-scale relief in the proximity of seepages. Proper gley soils develop in the proximity of seepages in upper parts of the slopes. A hillside slope reduces the process of bogging, and the surplus of water leads only to deep gleying of the soil profile. The general structure of the soils is Agg-G. In small depressions of the lower parts of slopes, peat-like soils occur with the horizon system of Ae-Agg-G. Low thickness of the profile, deep gleying and high concentration of organic matter are characteristic features of the soils. At the foot of slopes, in larger depressions, peatmud soils develop. The soils are built of silting up organic horizons, sometimes interbedded by mineral or organicmineral alluvium.

SOM content is a basic feature differentiating the soils of spring niches. The lowest content of SOM was noticed in the profile of proper gley soils $(5.0 \%)$, higher content in peat-like soils (up to $8.8 \%$ ), and the highest one in peatmud soils - up to $51.0 \%$ (Table 1). SOM is slightly humified - the humification rate from 9.8 to $37.3 \%$ (Table 2). The majority of humic acids in relation to fulvic acids is a favorable feature. High values of the absorbance ratio $\mathrm{E}_{4 / 6}$ confirmed low aromaticity of humic acids. The observed properties of SOM can result from limitation of the humification process in conditions of water surplus. Very low 
Table 1. Selected chemical properties of the soils

\begin{tabular}{|c|c|c|c|c|c|c|c|}
\hline Horizon & $\begin{array}{l}\text { Depth } \\
{[\mathrm{cm}]}\end{array}$ & $\begin{array}{c}\mathrm{pH} \\
\text { in } \mathrm{H}_{2} \mathrm{O}\end{array}$ & $\begin{array}{c}\mathrm{pH} \\
\text { in } 1 \mathrm{M} \mathrm{KCl}\end{array}$ & $\begin{array}{c}\mathrm{CaCO}_{3} \\
{[\%]}\end{array}$ & $\begin{array}{c}\text { Loss on } \\
\text { ignition } \\
{[\%]}\end{array}$ & 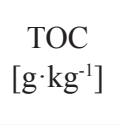 & $\begin{array}{l}\text { TOC/ } \\
\text { TON }\end{array}$ \\
\hline \multicolumn{8}{|c|}{ niche $\mathrm{nr} 1$ - proper gley soil } \\
\hline Agg & $0-20$ & 7.0 & 6.4 & 0.0 & 5.0 & 24.4 & 19 \\
\hline G1 & $20-44$ & 7.5 & 6.6 & $<0.1$ & 3.3 & - & - \\
\hline G2 & $44-62$ & 7.7 & 6.7 & $<0.1$ & 3.1 & - & - \\
\hline G3 & $62-110$ & 7.4 & 6.3 & 0.0 & 1.1 & - & - \\
\hline \multicolumn{8}{|c|}{ niche $\mathrm{nr} 2$ - peat-mud soil } \\
\hline POtmn & $0-15$ & 6.6 & 6.2 & 0.0 & 50.6 & 267 & 15 \\
\hline O1tmn & $15-42$ & 6.4 & 6.0 & 0.0 & 34.1 & 182 & 15 \\
\hline $\mathrm{O} 2 \mathrm{tmn}$ & $42-70$ & 6.8 & 6.0 & 0.0 & 36.5 & 199 & 17 \\
\hline $\mathrm{n}$ & $70-90$ & 7.1 & 6.1 & 0.0 & 16.0 & 84.0 & 20 \\
\hline $\mathrm{O} 3 \mathrm{mn}$ & $90-110$ & 6.9 & 6.1 & 0.0 & 23.2 & 127 & 16 \\
\hline $\mathrm{D}$ & $110-150$ & - & - & 0.0 & 1.4 & - & - \\
\hline \multicolumn{8}{|c|}{ niche nr 3 - peat-like soil } \\
\hline $\mathrm{Ae}$ & $0-24$ & 6.5 & 6.0 & 0.0 & 8.6 & 43.2 & 20 \\
\hline Agg & $24-54$ & 6.7 & 6.5 & 0.0 & 8.8 & 46.2 & 24 \\
\hline G & $54-80$ & 6.7 & 6.3 & $<0.1$ & 1.7 & - & - \\
\hline \multicolumn{8}{|c|}{ niche $\mathrm{nr} 4$ - peat-mud soil } \\
\hline POtmn & $0-34$ & 6.1 & 5.4 & 0.0 & 30.9 & 197 & 32 \\
\hline Otmn & $34-70$ & 6.6 & 5.9 & 0.0 & 25.6 & 128 & 18 \\
\hline $\mathrm{n}$ & $70-82$ & 6.6 & 5.5 & 0.0 & 10.4 & 45.7 & 16 \\
\hline $\mathrm{D}$ & $82-110$ & 7.5 & 6.4 & $<0.1$ & 1.7 & - & - \\
\hline \multicolumn{8}{|c|}{ niche nr 5 - peat-mud soil } \\
\hline POtmn & $0-22$ & 6.7 & 6.2 & 0.0 & 26.4 & 138 & 14 \\
\hline Otmn & $22-47$ & 6.5 & 6.1 & 0.0 & 51.0 & 271 & 16 \\
\hline $\mathrm{D}$ & $47-80$ & 7.0 & 6.2 & $<0.1$ & 1.7 & - & - \\
\hline
\end{tabular}

- not analyzed.

concentration of CKF1a fraction can indicate high intensity of leaching of dissolved organic matter (Table 2).

$\mathrm{SOM}$ influences the physical and chemical properties of the soils of spring niches. An increase of SOM content leads to a decrease of bulk density and specific density, as well as an increase of total porosity and specific surface area (Table 3). Maximum values of bulk density were noticed in the mineral bed of organic soils and minimum values in organic horizons of peat-mud soils. Total porosity ranged from 38.4 to $89.2 \%$. The lowest porosity was observed in the profile of proper gley soils, higher porosity - in peat-like soils and the highest one in organic horizons of peat-mud soils (Table 3). Similar trends are observed for specific surface area, which was $8.6-22.6 \mathrm{~m}^{2} \cdot \mathrm{g}^{-1}$ for proper gley soils, $14.5-26.4 \mathrm{~m}^{2} \cdot \mathrm{g}^{-1}$ for peat-like soils and $36.4-46.5 \mathrm{~m}^{2} \cdot \mathrm{g}^{-1}$ for peat-mud soils. The observed values are not high. This can result from low content of the clay fraction and low degree of SOM humification.

The feeding water significantly affects the soil reaction in spring niches. $\mathrm{pH}$ of the soils in the analyzed profiles 
Table 2. Fractional composition of soil organic matter (explanation of symbols in the text)

\begin{tabular}{|c|c|c|c|c|c|c|c|c|c|c|}
\hline \multirow{3}{*}{ Horizon } & \multirow{2}{*}{$\begin{array}{l}\text { CKF1a } \\
{[0.05 \mathrm{M}} \\
\left.\mathrm{H}_{2} \mathrm{SO}_{4}\right]\end{array}$} & \multicolumn{6}{|c|}{$0.1 \mathrm{M} \mathrm{Na}_{4} \mathrm{P}_{2} \mathrm{O}_{7}+0.1 \mathrm{M} \mathrm{NaOH}$} & \multirow{2}{*}{$\begin{array}{c}\mathrm{CKH} 2 \\
{[0.1 \mathrm{M}} \\
\mathrm{NaOH}]\end{array}$} & \multirow{2}{*}{$\begin{array}{c}\mathrm{CKHCa} \\
{[\mathrm{CKH} 1-} \\
\mathrm{CKH} 2]\end{array}$} & \multirow[b]{2}{*}{$\mathrm{CPP}$} \\
\hline & & CKH1 & CKF1 & $\mathrm{CKH}+\mathrm{CKF} 1$ & \multirow{2}{*}{ CKH:CKF } & $\begin{array}{c}\text { Humification } \\
\text { rate }\end{array}$ & \multirow{2}{*}{$\mathrm{E}_{4 / 6}$} & & & \\
\hline & $\%$ & \multicolumn{3}{|c|}{$\%$} & & $\%$ & & \multicolumn{3}{|c|}{$\%$} \\
\hline \multicolumn{11}{|c|}{ niche $\mathrm{nr} 1$ - proper gley soil } \\
\hline Agg & 0.06 & 0.26 & 0.15 & 0.42 & 1.73 & 17.0 & 7.82 & 0.15 & 0.12 & 2.02 \\
\hline \multicolumn{11}{|c|}{ niche $\mathrm{nr} 2$ - peat-mud soil } \\
\hline POtmn & 0.32 & 1.99 & 1.37 & 3.35 & 1.45 & 12.6 & 5.69 & 1.14 & 0.85 & 23.3 \\
\hline O1tmn & 0.18 & 1.90 & 0.85 & 2.75 & 2.24 & 15.1 & 5.85 & 1.31 & 0.59 & 15.4 \\
\hline $\mathrm{O} 2 \mathrm{tmn}$ & 0.18 & 2.01 & 0.86 & 2.87 & 2.35 & 14.4 & 5.56 & 0.98 & 1.04 & 17.0 \\
\hline $\mathrm{n}$ & 0.10 & 1.50 & 0.59 & 2.09 & 2.56 & 24.9 & 4.73 & 0.58 & 0.92 & 6.31 \\
\hline $\mathrm{O} 3 \mathrm{mn}$ & 0.10 & 1.01 & 2.32 & 3.33 & 0.44 & 26.2 & 5.64 & 0.61 & 0.40 & 9.40 \\
\hline \multicolumn{11}{|c|}{ niche $\mathrm{nr} 3$ - peat-like soil } \\
\hline $\mathrm{Ae}$ & 0.14 & 0.44 & 0.32 & 0.76 & 1.39 & 17.7 & 7.00 & 0.36 & 0.09 & 3.56 \\
\hline Agg & 0.10 & 0.44 & 0.30 & 0.74 & 1.45 & 15.9 & 6.07 & 0.33 & 0.10 & 3.89 \\
\hline \multicolumn{11}{|c|}{ niche $\mathrm{nr} 4$ - peat-mud soil } \\
\hline POtmn & 0.24 & 1.91 & 1.14 & 3.05 & 1.68 & 15.5 & 6.27 & 1.41 & 0.51 & 16.7 \\
\hline Otmn & 0.21 & 0.94 & 0.47 & 1.41 & 1.99 & 11.0 & 5.12 & 0.88 & 0.05 & 11.4 \\
\hline $\mathrm{n}$ & 0.18 & 1.37 & 0.34 & 1.70 & 4.09 & 37.3 & 4.22 & 0.62 & 0.75 & 2.87 \\
\hline \multicolumn{11}{|c|}{ niche $\mathrm{nr} 5$ - peat-mud soil } \\
\hline POtmn & 0.31 & 2.48 & 1.07 & 3.55 & 2.33 & 25.7 & 6.16 & 1.48 & 1.00 & 10.3 \\
\hline Otmn & 0.26 & 1.80 & 0.86 & 2.66 & 2.09 & 9.8 & 5.85 & 0.74 & 1.06 & 24.4 \\
\hline
\end{tabular}

ranged from 6.1 to 7.7 (Table 1). The content of carbonates was very low. The lack of accumulation of carbonates probably results from the presence of very acid, calciumpoor deposits on the water-bearing layer.

Soils of spring niches were in general rich in all forms of nitrogen (Table 4). Concentration of TON was the lowest in proper gley soils $\left(0.34-1.29 \mathrm{~g} \cdot \mathrm{kg}^{-1}\right)$, higher in peat-like

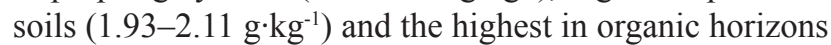
of peat-mud soils (4.38-17.45 $\left.\mathrm{g} \cdot \mathrm{kg}^{-1}\right)$ (Table 4). TOC:TON ratio ranged from $14: 1$ to $32: 1$. In general, lower values of the ratio were observed in superficial horizons in relation to subsurface horizons (Table 1).

The concentration of the easily-hydrolyzing form of nitrogen was $30.8-500.3 \mathrm{mg} \cdot \mathrm{kg}^{-1}$ of soil $(1.3-5.0 \%$ in relation to TON) (Table 4). Kalembasa and Becher (2009) recorded the concentration of $\mathrm{N}_{h}$ in the range of 441-609 $\mathrm{mg} \cdot \mathrm{kg}^{-1}$ and the contribution of the aforementioned form between 20.7 and $24.9 \%$ of TON. The concentration of water-extractable forms of nitrogen was also low, especially the nitrate form $\left(\mathrm{N}-\mathrm{NO}_{3}\right)$. Low concentration of $\mathrm{N}$ $\mathrm{NO}_{3}$ in soils of spring niches can from the limited nitrification process due to water surplus (Jekatierynczuk-Rudczyk 2006), as well as intensive denitrification, which is typical for bogged soils rich in organic matter (Davidson \& Ståhl 2000). Nitrates are intensively uptaken during vegetation season, which leads to reduction of $\mathrm{N}-\mathrm{NO}_{3}$ in soil solution. Samples of soils were taken in spring, when the concentration of nitrates is usually low compared to summer or autumn (Smólczyński \& Orzechowski 2009).

Soils of spring niches were rich in total phosphorus. The concentration of $\mathrm{P}_{t}$ was $0.30-0.45 \mathrm{~g} \cdot \mathrm{kg}^{-1}$ in proper gley soils, $0.37-0.50 \mathrm{~g} \cdot \mathrm{kg}^{-1}$ in peat-like soils and $0.63-$ $2.18 \mathrm{~g} \cdot \mathrm{kg}^{-1}$ in organic horizons of peat-mud soils (Table 4). The contribution of water-extractable and plant-available forms of phosphorus was generally low. The highest concentrations of $\mathrm{P}_{\mathrm{pa}}$ were in superficial horizons (compared 
Table 3. Physical properties of the soils

\begin{tabular}{|c|c|c|c|c|c|c|}
\hline Horizon & $\begin{array}{l}\text { Depth } \\
{[\mathrm{cm}]}\end{array}$ & $\begin{array}{l}\text { Textural group } \\
\text { of mineral part }\end{array}$ & $\begin{array}{c}\text { Clay content } \\
{[\%]}\end{array}$ & $\begin{array}{l}\text { Bulk density } \\
{\left[\mathrm{g} \cdot \mathrm{cm}^{-3}\right]}\end{array}$ & $\begin{array}{c}\text { Total porosity } \\
{[\%]}\end{array}$ & $\begin{array}{c}\text { Specific } \\
\text { surface area } \\
{\left[\mathrm{m}^{2} \cdot \mathrm{g}^{-1}\right]}\end{array}$ \\
\hline \multicolumn{7}{|c|}{ niche $\mathrm{nr} 1$ - proper gley soil } \\
\hline Agg & $0-20$ & Loamy sand & 4.1 & 1.03 & 60.2 & 22.6 \\
\hline G1 & $20-44$ & Sandy loam & 6.4 & 1.25 & 51.4 & 19.8 \\
\hline G2 & $44-62$ & Loamy sand & 6.3 & 1.20 & 54.4 & 15.6 \\
\hline G3 & $62-110$ & Sand & 2.0 & 1.48 & 44.6 & 8.6 \\
\hline \multicolumn{7}{|c|}{ niche $\operatorname{nr} 2$ - peat-mud soil } \\
\hline POtmn & $0-15$ & - & - & 0.20 & 89.1 & - \\
\hline O1tmn & $15-42$ & - & - & 0.23 & 89.2 & 40.1 \\
\hline $\mathrm{O} 2 \mathrm{tmn}$ & $42-70$ & - & - & 0.27 & 86.3 & 33.8 \\
\hline $\mathrm{n}$ & $70-90$ & Sandy loam & 8.9 & 0.56 & 72.9 & 38.1 \\
\hline $\mathrm{O} 3 \mathrm{mn}$ & $90-110$ & - & - & 0.23 & 89.8 & 40.6 \\
\hline $\mathrm{D}$ & $110-150$ & Sandy loam & 12.3 & 1.60 & 39.2 & 19.1 \\
\hline \multicolumn{7}{|c|}{ niche $\mathrm{nr} 3$ - peat-like soil } \\
\hline Ae & $0-24$ & Loamy sand & 3.1 & 0.76 & 69.6 & 26.4 \\
\hline Agg & $24-54$ & Loamy sand & 0.0 & 0.68 & 72.1 & 23.5 \\
\hline G & $54-80$ & Sandy loam & 6.6 & 1.60 & 39.2 & 14.5 \\
\hline \multicolumn{7}{|c|}{ niche $\mathrm{nr} 4$ - peat-mud soil } \\
\hline POtmn & $0-34$ & - & - & 0.32 & 84.5 & 45.3 \\
\hline Otmn & $34-70$ & - & - & 0.46 & 79.6 & 36.4 \\
\hline $\mathrm{n}$ & $70-82$ & Sandy loam & 6.4 & 0.80 & 66.7 & 40.6 \\
\hline $\mathrm{D}$ & $82-110$ & Sandy loam & 12.3 & 1.62 & 38.4 & 19.1 \\
\hline \multicolumn{7}{|c|}{ niche $\mathrm{nr} 5$ - peat-mud soil } \\
\hline POtmn & $0-22$ & - & - & 0.33 & 84.6 & 38.1 \\
\hline Otmn & $22-47$ & - & - & 0.24 & 87.6 & 46.5 \\
\hline $\mathrm{D}$ & $47-80$ & Sandy loam & 8.3 & 1.23 & 52.3 & 18.3 \\
\hline
\end{tabular}

- not analyzed.

to subsurface horizons) of soils. The contribution of $\mathrm{P}_{\mathrm{pa}}$ in relation to $\mathrm{P}_{\mathrm{t}}$ was $2.1-6.4 \%$ in gley soils, $3.2-4.4 \%$ in bogged horizons of peat-mud soils and $0.6-1.9 \%$ in subsurface organic horizons of these soils. The contribution of the water-extractable form of phosphorus was $0.2-1.1 \%$ (Table 4). Leaching is probably the main cause of low $\mathrm{P}_{\mathrm{a}}$ concentration, but some phosphorus can also be immobilized by iron (Sharpley 1995).
The concentration of total potassium was 9.43-15.20 $\mathrm{g} \cdot \mathrm{kg}^{-1}$ in proper gley soils, $12.44-13.73 \mathrm{~g} \cdot \mathrm{kg}^{-1}$ in peat-like soils, $13.13-18.02 \mathrm{~g} \cdot \mathrm{kg}^{-1}$ in the mineral bed of peat-mud soils and 5.91-10.96 $\mathrm{g} \cdot \mathrm{kg}^{-1}$ in organic horizons of these soils (Table 4). The contribution of plant-available forms of potassium was $0.3-0.9 \%$ in relation to $\mathrm{K}_{t}$. High mobility of potassium in the environment is probable reason of the observed low concentration of $\mathrm{K}_{\mathrm{pa}}$ and $\mathrm{K}_{\mathrm{a}}$ in soils of spring niches. 
Table 4. Concentration of different forms of nitrogen, phosphorus and potassium

\begin{tabular}{|c|c|c|c|c|c|c|c|c|c|c|}
\hline \multirow[b]{2}{*}{ Horizon } & \multicolumn{4}{|c|}{ Nitrogen } & \multicolumn{3}{|c|}{ Phosphorus } & \multicolumn{3}{|c|}{ Potassium } \\
\hline & $\begin{array}{c}\mathrm{TON} \\
{\left[\mathrm{g} \cdot \mathrm{kg}^{-1}\right]}\end{array}$ & $\begin{array}{c}\mathrm{N}_{\mathrm{h}} \\
{\left[\mathrm{mg} \cdot \mathrm{kg}^{-1}\right]}\end{array}$ & $\begin{array}{c}\mathrm{DON} \\
{\left[\mathrm{mg} \cdot \mathrm{kg}^{-1}\right]}\end{array}$ & $\begin{array}{c}\mathrm{N}-\mathrm{NO}_{3} \\
{\left[\mathrm{mg} \cdot \mathrm{kg}^{-1}\right]}\end{array}$ & $\begin{array}{c}\mathrm{P}_{\mathrm{t}} \\
{\left[\mathrm{g} \cdot \mathrm{kg}^{-1}\right]}\end{array}$ & $\begin{array}{c}\mathrm{P}_{\mathrm{pa}} \\
{\left[\mathrm{mg} \cdot \mathrm{kg}^{-1}\right]}\end{array}$ & $\begin{array}{c}\mathrm{P}_{\mathrm{a}} \\
{\left[\mathrm{mg} \cdot \mathrm{kg}^{-1}\right]}\end{array}$ & $\begin{array}{c}\mathrm{K}_{\mathrm{t}} \\
{\left[\mathrm{g} \cdot \mathrm{kg}^{-1}\right]}\end{array}$ & $\begin{array}{c}\mathrm{K}_{\mathrm{pa}} \\
{\left[\mathrm{mg} \cdot \mathrm{kg}^{-1}\right]}\end{array}$ & $\begin{array}{c}\mathrm{K}_{\mathrm{a}} \\
{\left[\mathrm{mg} \cdot \mathrm{kg}^{-1}\right]}\end{array}$ \\
\hline \multicolumn{11}{|c|}{ niche $\mathrm{nr} 1$ - proper gley soil } \\
\hline Agg & 1.29 & 59.2 & 70.6 & 5.0 & 0.38 & 17.6 & 2.4 & 13.1 & 37.9 & 18.6 \\
\hline G1 & 0.96 & 48.2 & 65.8 & 5.0 & 0.45 & 16.9 & 2.9 & 15.2 & 49.0 & 25.3 \\
\hline G2 & 0.97 & 30.8 & 72.2 & 4.6 & 0.30 & 11.2 & 2.5 & 12.0 & 35.7 & 18.2 \\
\hline G3 & 1.29 & - & 38.1 & 4.8 & 0.33 & 21.0 & 2.5 & 9.43 & 25.7 & 17.6 \\
\hline \multicolumn{11}{|c|}{ niche $\mathrm{nr} 2$ - peat-mud soil } \\
\hline POtmn & 1.45 & 500 & 351 & 17.6 & 2.18 & 69.0 & 19.5 & 8.01 & 155 & 111 \\
\hline O1tmn & 11.94 & 223 & 99.4 & 7.0 & 1.55 & 19.6 & 7.2 & 11.0 & 75.2 & 31.5 \\
\hline $\mathrm{O} 2 \mathrm{tmn}$ & 11.87 & 170 & 112 & 7.0 & 1.91 & 15.5 & 5.8 & 9.54 & 51.6 & 23.2 \\
\hline $\mathrm{N}$ & 4.28 & 96.9 & 78.7 & 7.2 & 1.69 & 15.2 & 4.0 & 16.1 & 93.2 & 25.6 \\
\hline $\mathrm{O} 3 \mathrm{mn}$ & 7.72 & 97.2 & 58.5 & 14.0 & 0.99 & 5.5 & 2.9 & 7.35 & 40.2 & 17.6 \\
\hline D & & - & - & - & 0.37 & - & - & 13.1 & - & - \\
\hline \multicolumn{11}{|c|}{ niche $\mathrm{nr} 3$ - peat-like soil } \\
\hline $\mathrm{Ae}$ & 2.11 & 90.3 & 94.6 & 5.2 & 0.40 & 23.5 & 2.9 & 12.4 & 30.2 & 15.8 \\
\hline Agg & 1.93 & 65.7 & 52.1 & 3.1 & 0.50 & 10.6 & 1.3 & 13.7 & 38.5 & 16.0 \\
\hline G & 0.27 & - & - & - & 0.37 & - & - & 13.1 & 40.6 & - \\
\hline \multicolumn{11}{|c|}{ niche $\mathrm{nr} 4$ - peat-mud soil } \\
\hline POtmn & 6.10 & 241 & 146 & 7.9 & 0.63 & 27.5 & 5.8 & 9.47 & 87.4 & 37.6 \\
\hline Otmn & 7.03 & 164 & 129 & 6.0 & 0.76 & 12.9 & 2.5 & 10.8 & 35.0 & 11.2 \\
\hline $\mathrm{N}$ & 2.87 & 128 & 112 & 5.4 & 0.58 & 21.6 & 3.0 & 13.3 & 44.5 & 14.2 \\
\hline $\mathrm{D}$ & 0.33 & - & - & - & 0.40 & - & - & 18.0 & 55.1 & - \\
\hline \multicolumn{11}{|c|}{ niche $\mathrm{nr} 5$ - peat-mud soil } \\
\hline POtmn & 9.65 & 236 & 216 & 8.5 & 0.71 & 24.8 & 6.1 & 9.48 & 27.4 & 14.1 \\
\hline Otmn & 17.02 & 226 & 318 & 9.1 & 0.70 & 13.2 & 7.8 & 5.91 & 21.3 & 20.6 \\
\hline D & 0.42 & - & - & - & 0.20 & - & - & 15.7 & 42.9 & - \\
\hline
\end{tabular}

- not analyzed.

Large variability of CEC was observed in the studied profiles. Poor in SOM and clay Proper gley soils, poor in SOM and clay, have small sorption capacity CEC 5.20$12.14 \mathrm{cmol}_{\mathrm{c}} \cdot \mathrm{kg}^{-1}$. Much higher values of CEC were observed in organic horizons of peat-mud soils - up to 132.83 $\mathrm{cmol}_{\mathrm{c}} \cdot \mathrm{kg}^{-1}$. Bases dominated in the soil sorption complex (over 99.3\%), especially calcium bases (Table 5). High saturation of the soil sorption complex with calcium results from the influence exerted by the feeding water, where calcium is the basic component (Jonczak 2010). High saturation of the soil sorption complex with calcium is typical of the soils with neutral or alkaline $\mathrm{pH}$ (Laskowski \& Tołoczko 2001; Jaworska et al. 2008).

Different buffer properties were observed in particular profiles of the soils (Fig. 1). Proper gley soils had the lowest buffer capacity. The highest buffer capacity was noticed for peat-like and peat-mud soils. Basic buffer in soils of spring niches in the valley of the Jarosławianka 
Table 5. Concentration of exchangeable cations, total of exchangeable bases (TEB), cation exchange capacity (CEC) and base saturation (BS)

\begin{tabular}{|c|c|c|c|c|c|c|c|c|c|c|}
\hline \multirow{2}{*}{ Horizon } & \multirow{2}{*}{$\begin{array}{l}\text { Depth } \\
{[\mathrm{cm}]}\end{array}$} & \multicolumn{6}{|c|}{ Exchangeable cations $\left[\mathrm{cmol}_{\mathrm{c}} \cdot \mathrm{kg}^{-1}\right]$} & \multirow{2}{*}{$\begin{array}{c}\text { TEB } \\
{\left[\mathrm{cmol}_{\mathrm{c}}\right.} \\
\left.\cdot \mathrm{kg}^{-1}\right]\end{array}$} & \multirow{2}{*}{$\begin{array}{c}\mathrm{CEC} \\
{\left[\mathrm{cmol}_{\mathrm{c}} \cdot \mathrm{kg}^{-1}\right]}\end{array}$} & \multirow{2}{*}{$\begin{array}{l}\mathrm{BS} \\
{[\%]}\end{array}$} \\
\hline & & $\mathrm{Ca}^{2+}$ & $\mathrm{Mg}^{2+}$ & $\mathrm{Na}^{+}$ & $\mathrm{K}^{+}$ & $\mathrm{H}^{+}$ & $\mathrm{Al}^{3+}$ & & & \\
\hline \multicolumn{11}{|c|}{ niche $\mathrm{nr} 1$ - proper gley soil } \\
\hline Agg & $0-20$ & 10.9 & 0.90 & 0.20 & 0.12 & 0.03 & 0.005 & 12.1 & 12.1 & 99.8 \\
\hline G1 & $20-44$ & 11.2 & 0.93 & 0.27 & 0.19 & 0.02 & 0.005 & 12.6 & 12.6 & 99.9 \\
\hline $\mathrm{G} 2$ & $44-62$ & 8.51 & 0.81 & 0.13 & 0.10 & 0.01 & 0.002 & 9.55 & 9.56 & 99.9 \\
\hline G3 & $62-110$ & 3.58 & 1.42 & 0.12 & 0.07 & 0.01 & 0.003 & 5.19 & 5.20 & 99.7 \\
\hline \multicolumn{11}{|c|}{ niche $\mathrm{nr} 2$ - peat-mud soil } \\
\hline POtmn & $0-15$ & 130 & 0.68 & 0.85 & 0.87 & 0.35 & 0.05 & 132 & 132 & 99.7 \\
\hline O1tmn & $15-42$ & 61.0 & 4.47 & 0.38 & 0.26 & 0.26 & 0.05 & 66.1 & 66.4 & 99.6 \\
\hline $\mathrm{O} 2 \mathrm{tmn}$ & $42-70$ & 53.2 & 1.62 & 0.32 & 0.17 & 0.22 & 0.05 & 55.4 & 55.6 & 99.6 \\
\hline $\mathrm{n}$ & $70-90$ & 27.5 & 1.22 & 0.23 & 0.30 & 0.04 & 0.004 & 29.2 & 29.3 & 99.9 \\
\hline $\mathrm{O} 3 \mathrm{mn}$ & $90-110$ & 49.3 & 2.84 & 0.34 & 0.12 & 0.11 & 0.01 & 52.6 & 52.7 & 99.8 \\
\hline $\mathrm{D}$ & $110-150$ & - & - & - & - & - & - & - & - & - \\
\hline \multicolumn{11}{|c|}{ niche nr 3 - peat-like soil } \\
\hline Ae & $0-24$ & 17.7 & 1.22 & 0.19 & 0.10 & 0.02 & 0.003 & 19.2 & 19.2 & 99.9 \\
\hline Agg & $24-54$ & 21.9 & 1.02 & 0.22 & 0.12 & 0.04 & 0.005 & 23.2 & 23.3 & 99.8 \\
\hline G & $54-80$ & 6.90 & 0.81 & 0.11 & 0.13 & 0.02 & 0.007 & 7.96 & 7.98 & 99.7 \\
\hline \multicolumn{11}{|c|}{ niche $\mathrm{nr} 4$ - peat-mud soil } \\
\hline POtmn & $0-34$ & 42.3 & 8.93 & 0.39 & 0.28 & 0.35 & 0.05 & 51.9 & 52.2 & 99.3 \\
\hline Otmn & $34-70$ & 49.8 & 3.45 & 0.38 & 0.14 & 0.22 & 0.02 & 53.7 & 54.0 & 99.6 \\
\hline $\mathrm{n}$ & $70-82$ & 35.2 & 2.44 & 0.23 & 0.17 & 0.03 & 0.001 & 38.0 & 38.0 & 99.9 \\
\hline $\mathrm{D}$ & $82-110$ & 8.20 & 0.41 & 0.28 & 0.22 & 0.01 & 0.001 & 9.11 & 9.12 & 99.9 \\
\hline \multicolumn{11}{|c|}{ niche $\mathrm{nr} 5$ - peat-mud soil } \\
\hline POtmn & $0-22$ & 67.5 & 4.06 & 0.57 & 0.13 & 0.22 & 0.02 & 72.2 & 72.4 & 99.7 \\
\hline Otmn & $22-47$ & 89.3 & 3.65 & 0.61 & 0.10 & 0.22 & 0.05 & 93.6 & 93.8 & 99.8 \\
\hline $\mathrm{D}$ & $47-80$ & 7.37 & 0.81 & 0.15 & 0.15 & 0.02 & 0.003 & 8.48 & 8.50 & 99.8 \\
\hline
\end{tabular}

- not analyzed.

River is ion-exchange buffer and SOM. Carbonate buffer do not play an important role because of very low concentration of carbonates. An increase of soil buffer capacity was observed along with an increase in the SOM content and CEC. Ion-exchange buffer can be effective in acids neutralization in soils of high CEC. The studies of Malczyk et al. (2008) show that ion-exchange buffer can effectively neutralize acids in soils of CEC 7.96-37.42 $\mathrm{cmol}_{\mathrm{c}} \cdot \mathrm{kg}^{-1}$. In the soils of spring niches CEC is higher. If there is no calcareous or high base saturation, ion-exchange buffer is the main and effective way of acidity neutralization.

Strong influence exerted by SOM, clay content and specific surface area on many soil properties in spring niches is confirmed by the results of statistical analysis (Table 6). 

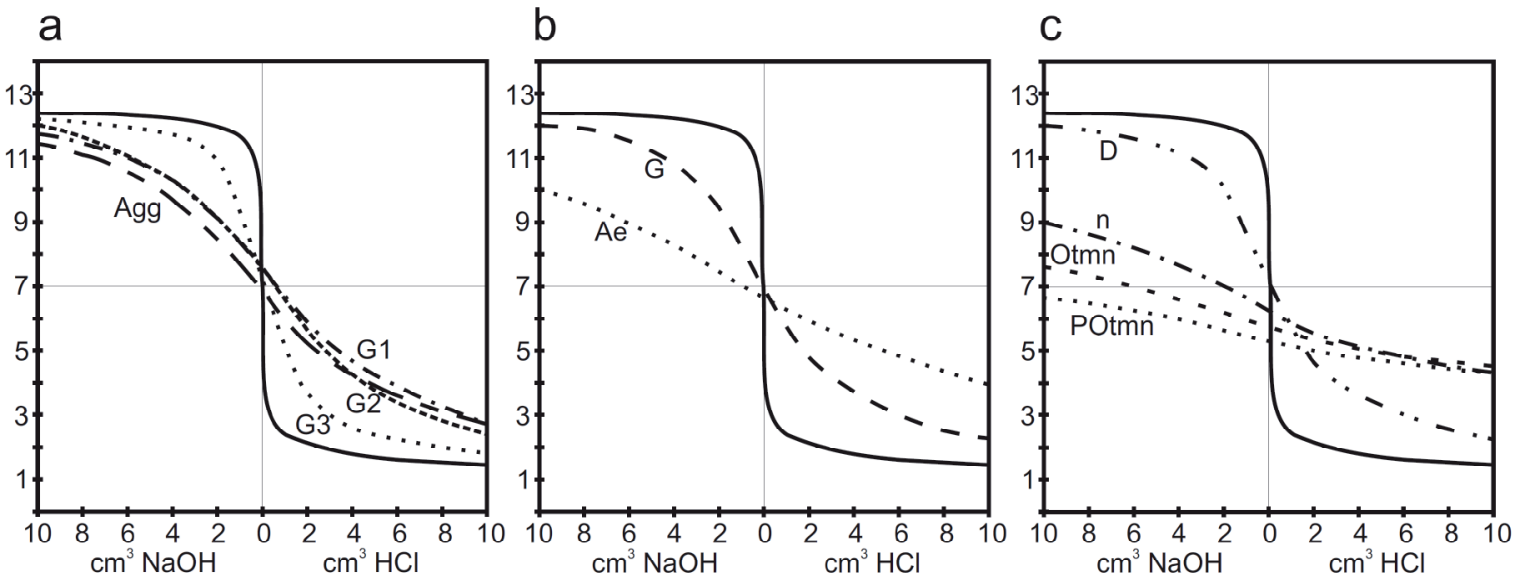

Figure 1. Buffer curves of: a) proper gley soil of niche $\mathrm{nr}$ 1, b) peat-like soil of niche $\mathrm{nr} 3$, c) peat-mud soil of niche $\mathrm{nr} 4$; solid line - buffer curve of quartz sand

Table 6. Correlations between SOM concentration, SOM humification rate, clay content, specific surface area and some chemical properties of the soils $(\mathrm{p}<0.05)$

\begin{tabular}{|c|c|c|c|c|}
\hline $\begin{array}{l}\text { Soil chemical } \\
\text { properties }\end{array}$ & SOM & $\begin{array}{l}\text { Humification } \\
\text { rate }\end{array}$ & Clay content & $\begin{array}{c}\text { Specific surface } \\
\text { area }\end{array}$ \\
\hline TON & 0.98 & - & 0.77 & 0.72 \\
\hline $\mathrm{N}_{\mathrm{h}}$ & 0.84 & - & 0.70 & 0.82 \\
\hline DON & 0.81 & - & 0.75 & 0.59 \\
\hline $\mathrm{N}-\mathrm{NO}_{3}$ & 0.69 & - & 0.90 & 0.65 \\
\hline$P_{t}$ & 0.65 & - & - & - \\
\hline $\mathrm{P}_{\mathrm{pa}}$ & - & - & - & - \\
\hline $\mathrm{P}_{\mathrm{a}}$ & 0.77 & - & 0.80 & 0.67 \\
\hline $\mathrm{K}_{\mathrm{t}}$ & -0.80 & - & - & -0.58 \\
\hline $\mathrm{K}_{\mathrm{pa}}$ & - & - & - & - \\
\hline $\mathrm{K}_{\mathrm{a}}$ & 0.54 & - & - & - \\
\hline CEC & 0.93 & - & 0.70 & 0.84 \\
\hline $\mathrm{Ex} \mathrm{Ca*}$ & 0.92 & - & 0.70 & 0.82 \\
\hline Ex Mg* & - & - & 0.72 & 0.71 \\
\hline Ex Na* & 0.86 & - & 0.69 & 0.70 \\
\hline Ex K* & - & - & - & - \\
\hline Ex H* & 0.88 & - & 0.68 & 0.70 \\
\hline $\mathrm{Ex} \mathrm{Al} *$ & 0.92 & -0.60 & - & 0.63 \\
\hline
\end{tabular}

- lack of correlation

* exchangeable $\mathrm{Ca}, \mathrm{Mg}, \mathrm{Na}, \mathrm{K}, \mathrm{H}, \mathrm{Al}$ 


\section{Conclusions}

The performed analyses may lead to the following conclusions:

The water surplus is typical of spring niches' ecosystems and leads to the development of hydrogenic and semihydrogenic soils of different profile thickness.

In general, the characteristic feature of soils in spring niches is high concentration of SOM, which is slightly humified. In the fractional composition of SOM, humic acids dominate in relation to fulvic acids. Humic acids have low aromaticity.

Soils of spring niches are rich in all forms of N, P and $\mathrm{K}$, and poor in plant-available and water-extractable forms of these elements. The observed low content of plant-available and water-extractable forms of N, P and $\mathrm{K}$ is caused by permanent leaching of mineralization products by lotic water.

High concentration of SOM in the soils of spring niches has positive impact on soil sorption and buffer properties. The highest values of CEC were noticed in organic horizons of peat-mud soils. The ionic composition of the soil sorption complex was determined by the feeding water chemistry. Almost total base saturation of the soil sorption complex was observed in every niches. Calcium was the basic cation.

In the situation of a very low content of carbonates, ion-exchange buffer was a basic mechanism neutralizing the acids. The ion-exchange buffer was very effective due to high CEC and high base saturation.

\section{References}

Davidson T.E. \& Ståhl M., 2000, The influence of organic carbon on nitrogen transformations in five wetland soils, Soil Sci. Am. J. 64: 1129-1136.

Dziadowiec H. \& Gonet S.S., 1999, Przewodnik metodyczny do badań materii organicznej gleb [Methodological guide for soil organic matter study], Prace Komisji Naukowych PTG nr 120, Komisja Chemii Gleb, Zespół Materii Organicznej II/16, Warszawa.

Jaworska H., Kobierski M. \& Dąbkowska-Naskręt H., 2008, Kationowa pojemność wymienna i zawartość kationów wymiennych w glebach płowych o zróżnicowanym uziarnieniu [Cation exchange capacity and the content of exchangeable cations in luvisols of various texture], Soil Science Annual 59(1): 84-89.

Jekatierynczuk-Rudczyk E., 2005, Transformacja składu chemicznego wody w strefie źródlisk nizinnych [Transformation of water quality in the lowland springs], Stan i antropogeniczne zmiany jakości wód w Polsce, t. III, Wydawnictwo Uniwersytetu Łódzkiego, Łódź: 259-268.
Jekatierynczuk-Rudczyk E., 2006, Zmiany składu chemicznego wody w niszach źródlisk nizinnych [Transformations of water chemistry in the lowland springs niches], Dokumentacja Geograficzna 32, Idee i praktyczny uniwersalizm geografii, PAN IGiPZ, Warszawa: $113-118$.

Jekatierynczuk-Rudczyk E., 2007, Strefa hyporeiczna, jej funkcjonowanie i znaczenie [The hyporheic zone, its functioning and meaning], Kosmos 56(1-2): 181-196.

Jonczak J., 2010, Chemizm wód zasilających Jarosławiankę (Równina Sławieńska) [The chemistry of waters supplying Jarosławianka River (Sławieńska Plain)], Słupskie Prace Geograficzne, in print.

Kalembasa D. \& Becher M., 2009, Frakcje azotu w glebach torfowo-murszowych w dolinie górnego Liwca [Fractions of nitrogen in drained peat-muck soils located in the upper Liwiec River valley], Woda-ŚrodowiskoObszary Wiejskie 9(2): 73-82.

Laskowski S. \& Tołoczko W., 2001, Alterations of some chemical and physico-chemical properties of selected soils in field ecosystems, Acta Agrophysica 50: 177-188.

Malczyk P., Kobierski M., Jaworska H. \& DąbkowskaNaskręt H., 2008, Zależność między wybranymi właściwościami gleb i pojemnością buforową w glebach uprawnych regionu Kujaw i Pomorza [Relationships between selected soil properties and buffer capacity in arable soils from Kujawy-Pomorze Region, Poland], Soil Science Annual 59(1): 149-154.

Mazurek M., 2006, Wypływy wód podziemnych w południowej części dorzecza Parsęty [Groundwater outflows in the southern part of Parsęta drainage basin], Badania Fizjograficzne nad Polską Zachodnią, Seria A - Geografia Fizyczna 57: 101-118.

Osadowski Z., 2006, Threatened, protected and rate species of vascular plants in spring complexes in the central part of Polish Pomerania, Biodiv. Res. Conserv. 1-2: 174-180.

Sharpley A. N., 1995, Soil phosphorus dynamics: agronomic and environmental impacts, Ecological Engineering 5: 261-279.

Smólczyński S. \& Orzechowski M., 2009, Przebieg mineralizacji związków azotu w glebach torfowomurszowych o różnym stopniu zamulenia w krajobrazie młodoglacjalnym [Mineralization of nitrogen compounds in differently silted peat-muck soils in young glacial landscape], Woda-Środowisko-Obszary Wiejskie 9/1: 141-150.

Systematyka gleb Polski [Systematics of Polish soils], 1989, Rocz. Glebozn. 40( 3/4).

Wołejko L., 1996, Stan zachowania i potrzeby ochrony kompleksów źródliskowych na Pomorzu Zachodnim [State of preservation and needs for protection of spring complexes in the region of West Pomerania], Zeszyty Naukowe AR Szczecin, Seria Przyroda 173: 151-160. 